\title{
Persistence of Dromiciops gliroides in landscapes dominated by Pinus radiata plantations
}

\author{
Sandra V. Uribe ${ }^{*}$, Romina G. Chiappe and Cristián F. Estades
}

\begin{abstract}
Background: Monitos del monte (Dromiciops gliroides) are old-growth forest specialists and, thus, believed to be very sensitive to habitat transformation, although some recent studies show some level of plasticity of their habitat selection patterns.

Findings: In this note we report on records of D. gliroides living in a very modified environment, composed mostly by industrial pine plantations and small fragments of Nothofagus spp. forests and we report the extension of the northernmost limit of its currently known distribution.

Conclusions: Although highly reliant on native vegetation, Dromiciops gliroides has been able to persist in industrial forest landscapes dominated by pine plantations.
\end{abstract}

Keywords: Marsupial, fragmentation, conservation, habitat transformation

\section{Introduction}

The Monito del monte (Dromiciops gliroides) is the only representative of the order Microbiotheria [1, 2], closely related to Australian marsupials [3, 4] and it is classified as Near Threatened by IUCN [5]. Historically, this species has been considered an old-growth forest specialist, selecting stands with dense bamboo (Chusquea spp.) thickets, in which they build their nests [6-8]. Despite the latter, there is increasing evidence that $D$. gliroides can use environments such as secondary forests, shrublands and even sparse Eucalyptus plantations with a rich native understory $[9,10]$. Most of the studies on the ecology and biology of Monitos del monte have been conducted on populations in the evergreen forests of the Southern half of the species' range [e.g. [1, 9-15]]. In contrast, the information available for $D$. gliroides living in deciduous forests is very scant and anecdotal (e.g. [16, 17]). In this note we report on observations of some of the northernmost populations of $D$. gliroides, living in landscapes dominated by pine plantations.

\footnotetext{
* Correspondence: sandrum@gmail.com

School of Forest Science and Nature Conservation, University of Chile, Santa Rosa 11315, La Pintana, Santiago, Chile
}

\section{Methods}

The information presented in this note was collected as a part of two studies that we conducted in the Coastal Range of the Maule and Biobío regions of Central Chile, between 2008 and 2016 (see Additional file 1). The first study (S1, 2008-2012) involved live trapping of small mammals in seven landscapes dominated by industrial pine plantations, distributed from Constitución $\left(35^{\circ} 13^{\prime} \mathrm{S}\right.$ $72^{\circ} 08^{\prime} \mathrm{W}$ ) to Dichato ( $36^{\circ} 36^{\prime} \mathrm{S} 72^{\circ} 50^{\prime} \mathrm{W}$ ) (Fig. 1). At each site we installed five grids of $100(10 \times 10 \mathrm{~m})$ Sherman-like $(240 \times 80 \times 90 \mathrm{~mm})$ traps in mature $(17-20 \mathrm{y})$ pine stands. All traps were set up on the ground and baited with oats, remaining active during three nights. Each grid was assessed once during the breeding (October to Janury) and once during the non-breeding season (May to August). Thus, the total sampling effort was seven landscapes $\times 5$ grids $\times 100$ traps $\times 3$ nights $\times 2$ seasons $=21,000$ traps $\times$ night.

The second study (S2, 2012-2016) was also conducted in seven industrial forest landscapes distributed from Constitución $\left(35^{\circ} 30^{\prime} \mathrm{S} 72^{\circ} 23^{\prime} \mathrm{W}\right)$ to Cobquecura $\left(36^{\circ} 12^{\prime} \mathrm{S} 72^{\circ} 38^{\prime} \mathrm{W}\right)$ (Fig. 1), but this time we sampled small mammals in both pine plantations and native forests. At each site we installed a grid of 120 traps (60 2trap groups $25 \times 12 \mathrm{~m}$ from each other) in a Nothofagus 


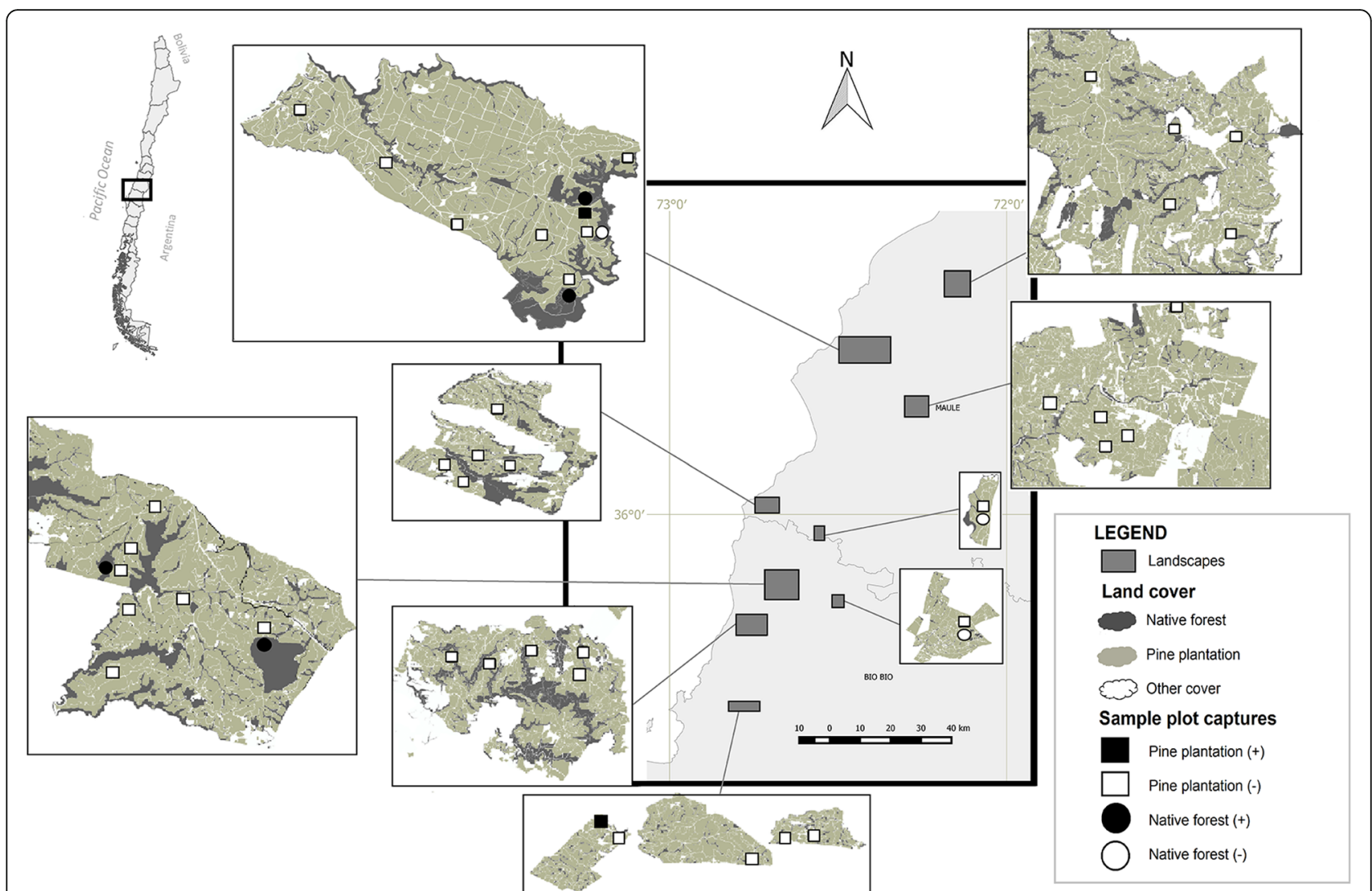

Fig. 1 Study area. Landscapes with the sample units. Black symbols represent sites with captures of monito del monte in pine plantations (square) and native forests (circle). Empty symbols are sites with no captures

spp. (N. glauca, N. obliqua and N. dombeyi) forest fragment and another in the adjacent mature pine plantation. As in the previous study, traps were put on the ground, baited with oats and remained active during three nights. Some sites were assessed more than once per season, so the total sampling effort for pine plantations was 18 sites/ times $\times 120$ traps $\times 3$ nights $=6,480$ traps $\mathrm{x}$ night during the breeding season, and 6 sites/times $\times 120$ traps $\times 3$ nights $=2,160$ traps $x$ night during the non-breeding season. For the native forests, sampling effort was 35 sites/ times $\times 120$ traps $\times 3$ nights $=12,600$ traps $\times$ night during the breeding season, and 6 sites/times $\times 120$ traps $\times 3$ nights $=2,160$ traps $\times$ night during the non-breeding season.

Although in both studies we ear-tagged most species, because of the small size of its ears and their low capture rates, we identified $D$. gliroides individuals through hair cuts. After sexing and weighting, we released all individuals in the same site of capture.

At all sampling plots we characterized the vegetation by visually estimating foliage volume of different strata and plant species [18]. We described the land use at each of the studied landscapes using a land cover data base for the country in 2014 [19]. The main land uses of each studied landscape are summarized in Table 1.

\section{Findings}

During our work we captured a total of 17 monitos del monte, two in pine plantations ( 0.067 individuals/1,000 traps contrast, the information available night) and 15 in native forest fragments (1.01 individuals/1,000 traps $\times$ night). The details of these captures are presented in Table 1.

The first individual recorded in pine plantations corresponded to a juvenile captured during the non-breeding season in S1, in a site $200 \mathrm{~m}$ from a narrow creek with native vegetation and $600 \mathrm{~m}$ from a 25-ha patch of native forest. There was a highly used forest road $20 \mathrm{~m}$ from the trap. The second record of the species in a pine stand was that of an adult captured $90 \mathrm{~m}$ from a 190-ha continuous patch of native vegetation during the second breeding season of S2 (Fig. 1). Both sites had a well developed understory ( $>20 \%$ cover).

The individuals recorded in native forest fragments were captured in four of the seven sites sampled, and two of them correspond to the northernmost records for 
Table 1 Studied landscapes and captures of Dromiciops gliroides in the coastal range of the Maule and Biobío regions

\begin{tabular}{|c|c|c|c|c|c|c|c|c|}
\hline \multirow{2}{*}{$\begin{array}{l}\text { Region/ } \\
\text { Municipality }\end{array}$} & \multirow[t]{2}{*}{ Landscape } & \multicolumn{3}{|c|}{ Land use (\% cover) } & \multicolumn{4}{|c|}{ Captures } \\
\hline & & Native forest & Pine & Other & $n$ & Coord. Lat/Long & Forest type & Study \\
\hline \multicolumn{9}{|l|}{ Maule } \\
\hline \multirow[t]{4}{*}{ /Constitución } & Quivolgo & 29 & 63 & 8 & 0 & & & \\
\hline & San Pedro-Las Cañas & 19 & 70 & 11 & 1 & $35^{\circ} 30^{\prime} 5.05^{\prime \prime} \mathrm{S} 72^{\circ} 22^{\prime} 42.88^{\prime \prime} \mathrm{W}$ & Pine & $\mathrm{S} 2$ \\
\hline & & & & & 1 & $\begin{array}{l}35^{\circ} 29^{\prime} 59.83^{\prime \prime} \mathrm{S} \\
72^{\circ} 22^{\prime} 38.45^{\prime \prime} \mathrm{W}\end{array}$ & Native & $\mathrm{S} 2$ \\
\hline & & & & & 12 & $\begin{array}{l}35^{\circ} 31^{\prime} 42.24^{\prime \prime} \mathrm{S} \\
72^{\circ} 22^{\prime} 58.22^{\prime \prime} \mathrm{W}\end{array}$ & Native & $\mathrm{S} 2$ \\
\hline /Pelluhue & Trehualemu & 37 & 51 & 12 & 0 & & & \\
\hline \multirow[t]{2}{*}{ /Cauquenes } & Name-Melencura & 32 & 61 & 7 & 0 & & & \\
\hline & Matanza segura & 27 & 58 & 15 & 0 & & & \\
\hline \multicolumn{9}{|l|}{ Biobío } \\
\hline /Cobquecura & Montezorro & 12 & 82 & 6 & 0 & & & \\
\hline \multirow[t]{2}{*}{ /Cobquecura-Quirihue } & Tollo-Guanaco & 26 & 57 & 17 & 1 & $\begin{array}{l}36^{\circ} 11^{\prime} 44.74^{\prime \prime S} \\
72^{\circ} 41^{\prime} 32.46^{\prime \prime} \mathrm{W}\end{array}$ & Native & S2 \\
\hline & & & & & 1 & $\begin{array}{l}36^{\circ} 13^{\prime} 14.85^{\prime \prime} \mathrm{S} \\
72^{\circ} 37^{\prime} 46.56^{\prime \prime} \mathrm{W}\end{array}$ & Native & S2 \\
\hline /Quirihue & Chipre & 7 & 92 & 1 & 0 & & & \\
\hline /Dichato & Crisoles-Leonera-Guineral & 18 & 67 & 15 & 1 & $\begin{array}{l}36^{\circ} 32^{\prime} 56.39^{\prime \prime} \mathrm{S} \\
72^{\circ} 52^{\prime} 51.91^{\prime \prime} \mathrm{W}\end{array}$ & Pine & S1 \\
\hline
\end{tabular}

the species. Interestingly, 12 individuals were captured during a three-day campaign in just one site.

\section{Discussion}

This note provides two pieces of novel information. Before our observations, Dromiciops gliroides had never been recorded in pine plantations. These observations were conducted in pine stands with dense $(>20 \%)$ understory. Our observations also expanded the known distribution of the species $35 \mathrm{Km}$ to the North (previous limit was Los Ruiles National Reserve 3550'S 72³0'W [17]). The latter agrees with the predictions by Martin [20] whose models give a $1-10 \%$ probability of presence of monito del monte between $34-36^{\circ} \mathrm{S}$ in the Coastal Range of Central Chile.

Although monitos del monte were recorded unfrequently in our studies $(0.09 \%$ of all captured small mammals), our results show that $D$. gliroides has been able to persist in an extremely altered environment. Also, the fact that we set up the traps on the ground and used a bait that is not particularly attractive to the species [11], suggests that we might have underestimated the abundance of the species.

The low abundance of $D$. gliroides in pine plantations is likely due to their simple vertical structure, which reduces their ability to climb and move through the foliage. Althouth some pine stands have well developed understories, bamboo (Chusquea spp.) thickets are uncommon in these artificial forests (average (SE), 267.3 $(123,6) \mathrm{m}^{3}$ foliage/ha, Uribe, unpublished data). This might favour the limited use of pine stands by monitos del monte, as these plants have been considered a key component of the species' breeding habitat, because of their importance for the construction of nests [1, 11]. Other key elements as ferns and vines are also uncommon in pine plantations. Fonturbel et al. [9] recorded $D$. gliroides at similar rates in native forests and Eucalyptus plantations, but in this unusual case, due to a lack of management, this stand had a rich native understory.

The native forest fragments studied by us had a much higher abundance of bamboos (average (SE), 1312.8 (540.6) $\mathrm{m}^{3}$ foliage/ha, Uribe, unpublished data) than pine stands, and, coincidentally, the capture rate of D. gliroides was an order of magnitude higher than that of plantations. However, this rate showed a significant variation among sites and campaigns, with $80 \%$ of the individuals captured in just one session in a plot of approximately 2 ha. We cannot begin to explain this aggregation of individuals by any evident factor associated to the habitat characteristics. In fact, this particular fragment had a below-average Chusquea cover $\left(936 \mathrm{~m}^{3}\right.$ foliage/ha). Also, the land use composition of San Pedro-Las Cañas was similar to the rest of the landscapes (19\% native forest and $70 \%$ pine plantation, vs an average (SE) of 23.5 (3.6) and 66.4 (4.9), respectively, 
Table 1). However, there is one anecdotal observation about this record that is worth mentioning. During the days in which we captured these animals, the neighboring plantations were being cut. We can only speculate on a transient aggregation of monitos in the native forest, while escaping from the timbering operations taking place in the nearby plantations. A study conducted by us in the area [21] showed no such effect for the rodent Abrothrix longipillis, as most individuals died crushed by the machinery because of their tendency to hide under the forest litter when in danger. However, a more mobile animal such as $D$. gliroides, that usually climbs trees for protection (authors' pers. obs), will likely try to abandon the tree harvesting area. Testing this hypothesis would be very important to understand the mechanisms affecting the long term persistence of this species in pine plantation landscapes. The available information is not sufficient to determine whether the presence of $D$. gliroides in landscapes dominated by pine plantations is a sign of some level of adaptation to this novel ecosystem (with its inherent disturbance regime [22]) or if it is only due to the "extinction debt" (i.e. populations are slowly declining towards extinction, [23]). However, the history of this region tends to favor the first explanation. For example, most plantations in this region of Chile are in their second or third 20-year rotation, which means that several generations of monitos have been born in these landscapes since the major transformations took place. Also, in the 1950's approximately a $45 \%$ of the landscape in the coastal range of South Central Chile was already transformed into agriculture [24, 25], whereas the current proportion of "open" land uses in this region is approximately $21 \%$ [26]. This means that the present landscape might be more favorable to forest specialists such as D. gliroides, who might avoid moving through non forested habitats [10].

In any of the latter cases, management of pine plantations has the potential to influence a significant proportion of $D$. gliroides populations. Two main issues that should be addressed are the potential transformation of pine plantations into breeding habitat for the species, via the improvement of the understory [27], and the enhancement of the role of pine plantations as connectors for populations living in native forest fragments. Specific management recommendations will likely arise after more detailed information on the species' ecology is obtained.

Recently, D'Elia et al. [28] proposed a division of $D$. gliroides into three different species. Should this new classification be adopted, our observations would then correspond to the northern species, $D$. bozinovici. The fact that a significant portion of this taxon's distribution range is dominated by pine plantations would make our observations even more relevant.

\section{Additional file}

Additional file 1: Table 1. Years of evaluation of different landscapes during Study 1 (S1). Numbers in parentheses are sample units in each field campaign. Table 2. Years of evaluation of study sites, during Study 2 (S2). Numbers in parentheses are the number of field campaigns for each site. (PDF 208 kb)

\section{Abbreviations \\ S1: First study (period 2008-2012); S2: Second study (period 2012-2016); SE: Standard error; y: Years}

\section{Acknowledgements}

Masisa, Mininco and Arauco companies kindly granted us access to their properties and provided us with cartographical information and some logistic support. Jimena Bustos, Martín Escobar, José Caro, Pilar Fernández, Gamal Naser, Valentina Echeverría and several other people assisted us in the field. We are grateful to all of them.

\section{Funding}

The studies from which we obtained the data reported in this note were funded by Fondecyt grants 1080463 and 1120314 to C.F. Estades.

Availability of data and material

Please contact author for data request.

\section{Authors' contributions}

SVU designed the studies, collected data and wrote the manuscript. RGC collected data and interpreted the results. CFE designed the studies, interpreted the results and wrote the manuscript.

\section{Authors information}

SVU Programa de Doctorado en Ciencias Silvoagropecuarias y Veterinarias, Universidad de Chile. RGC Programa de Magister en Áreas Silvestres y Conservación de la Naturaleza. Universidad de Chile. CFE Profesor titular en Facultad de Ciencias Forestales y de la Conservación de la Naturaleza, Universidad de Chile.

\section{Competing interests}

The authors declare that they have no competing interests.

\section{Consent for publications}

Not applicable.

\section{Ethics approval}

Captures were made under the following permits granted by the Chilean Agriculture and Livestock Service (SAG) to CFE: 2944(2008), 2794(2009), 3860(2010), 2916(2011), 4663(2012), 6513(2013), and 4056(2014-2016).

\section{Publisher's Note}

Springer Nature remains neutral with regard to jurisdictional claims in published maps and institutional affiliations.

Received: 22 September 2016 Accepted: 7 March 2017

Published online: 21 March 2017

\section{References}

1. Hershkovitz P. Dromiciops gliroides Thomas 1984, last of the microbiotheria (marsupialia), with a review of the family microbiotheriidae. Fieldiana Zool. 1999;93:1-60

2. Reig O. Noticia preliminar sobre la presencia de microbiotherinos vivientes en la fauna sudamericana. Invest Zool Chilenas. 1955;2:121-30.

3. Phillips MJ, McLenachan PA, Down C, Gibb GC, Penny D. Combined mitochondrial and nuclear DNA sequences resolve the interrelations of the major Australian marsupial radiation. Syst Biol. 2006;55(1):122-37.

4. Palma RE, Spotorno AE. Molecular systematics of marsupials based on the rRNA 125 mitochondrial gene: the phylogeny of Didelphimorphia and of the living fossil microbiotheriid Dromiciops gliroides Thomas. Mol Phylogenet Evol. 1999;13:525-35. 
5. Martin GM, Flores D, Teta P. 2015. Dromiciops gliroides. The IUCN Red List of Threatened Species 2015: e.T6834A22180239. http://dx.doi.org/10.2305/IUCN. UK.2015-4.RLTS.T6834A22180239.en. Downloaded on 1 November 2016.

6. Rodríguez-Cabal MA, Branch LC. Influence of habitat factors on the distribution and abundance of a marsupial seed disperser. J Mammal. 2011;92:1245-52.

7. Kelt DA. Efectos de la fragmentación del bosque lluvioso templado sobre los pequeños mamíferos. In: Grez AA, Simonetti JA, Bustamante RO, editors. Biodiversidad en ambientes fragmentados de chile: patrones y procesos a diferentes escalas. Santiago: Editorial Universitaria; 2006. p. 115-42. Naturwissenschaften (ver abrev). 2012;99:873-881.

8. Mann G. Los pequeños mamíferos de Chile. Gayana Zool. 1978;40:1-342.

9. Fontúrbel F, Candia AB, Botto-Mahan C. Nocturnal activity pattern of monito del monte (Dromiciops gliroides) in native and exotic habitats. J Mammal. 2014;95(6). doi:10.1644/13-MAMM-A-304

10. Fontúrbel FE, Franco M, Rodríguez-Cabal MA, Rivarola MD, Amico GC. Ecological consistency across space: a synthesis of the ecological aspects of Dromiciops gliroides in Argentina and Chile.

11. Celis-Diez JL, Hetz J, Marín-Vial PA, Fuster G, Necochea P, Vásquez RA, Jaksic FM, Armesto JJ. Population abundance, natural history, and habitat use by the arboreal marsupial dromiciops gliroides in rural chiloé island, Chile. BioOne. 2012:93:134-48.

12. Smith-Ramírez C, Celis-Diez JL, von Jenstchyk E, Jiménez JE, Armesto JJ. Habitat use remnant forest habitat by threatened arboreal marsupial Dromiciops gliroides (Microbiotheria) in a rural landscape of southern Chile. Wildlife Res. 2010;37:249-54.

13. Amico GC, Rodriguez-cabal MA, Aizen MA. The potential key seeddispersing role of the arboreal marsupial Dromiciops gliroides. Acta Oecologica. 2009;35:8-13.

14. Muñoz-Pedreros A, Lang BK, Bretos M, Meserve PL. Reproduction and development of Dromiciops gliroides (Marsupialia: Microbiotheriidae) in temperate rainforests of southern Chile. Gayana. 2005;69:225-33.

15. Marshal LG. Dromiciops australis. Mammalian Species. 1978;99:1-5.

16. Saavedra B, Simonetti JA. New records of dromiciops gliroides (microbiotheria: microbiotheridae) and geoxus valdivianus (rodentia: muridae) in central Chile: their implications for biogeography and conservation. Mammalia. 2001;65:96-100.

17. Lobos G, Charrier A, Carrasco G, Palma RE. Presence of Dromiciops gliroides (Microbiotheria: Microbiotheriidae) in the deciduous forests of central Chile. Mamm Biol. 2005;70:376-80.

18. Estades CF, Temple SA. Deciduous-forest bird communities in a fragmented landscape dominated by exotic pine plantations. Ecol Appl. 1999;9:573-85.

19. Zhao Y, Feng D, Yu L, Wang X, Chen Y, Bai Y, Hernández HJ, Galleguillos M, Estades CF, Biging GS, Radke JD, Gong P. Detailed dynamics land cover mapping of Chile: accuracy improvement by integrating multi-temporal data. Remote Sens Environ. 2016;183:170-85.

20. Martin GM. Geographic distribution and historical occurrence of Dromiciops gliroides Thomas (Metatheria: Microbiotheria). J Mammal. 2010;91:1025-35.

21. Escobar MAH, Uribe SV, Chiappe R, Estades CF. Effect of clearcutting operations on the survival rate of a small mammal. Plos One. 2015; doi:10.1371/journal.pone.0118883.

22. Estades CF, Escobar MAH. Los ecosistemas de las plantaciones de pino de la Cordillera de la Costa. In: Smith-Ramírez C, Armesto JJ, Valdovinos C, editors. Historia, biodiversidad y ecología de los bosques costeros de Chile. Santiago: Editorial Universitaria; 2005. p. 600-16.

23. Kuussaari M, Bommarco R, Heikkinen RK, Helm A, Krauss J, Lindborg R, Öckinger E, Pärtel M, Pino J, Rodà F, Stefanescu C, Teder Tiit, Zobel M and Steffan-Dewenter I. Extinction debt: a challenge for biodiversity conservation. Trends Ecol Evol. 2009; doi:10.1016/j.tree.2009.04.011.

24. Servicio Nacional de Estadísticas y Censos, III Censo Nacional Agrícola Ganadero. Tomo III. Núcleo Central II. Curicó, Talca, Maule, Linares y Ñuble. Chile: NEC; 1955. p. 1-252.

25. Servicio Nacional de Estadísticas y Censos, III Censo Nacional Agrícola Ganadero. Tomo IV. Concepción y La Frontera. Concepción, Arauco, Biobío, Malleco y Cautín. Chile: NEC; 1955. p. 1-282.

26. Instituto Nacional de Estadísticas. VI Censo Nacional Agropecuario. Chile: INE; 2007. p. 1-214.

27. Simonetti JA, Grez AA, Estades CF. Providing habitat for native mammals through understory enhancement in forestry plantation. Conserv Biol. 2013;27:1117-21.

28. D'Elía G, Hurtado N, D'Anarto. Alpha taxonomy of Dromiciops (Microbiotheriidae) with the description of 2 new species of monito del monte. J Mam. 2016. doi:10.1093/jmammal/gyw068.

\section{Submit your next manuscript to BioMed Central and we will help you at every step:}

- We accept pre-submission inquiries

- Our selector tool helps you to find the most relevant journal

- We provide round the clock customer support

- Convenient online submission

- Thorough peer review

- Inclusion in PubMed and all major indexing services

- Maximum visibility for your research

Submit your manuscript at www.biomedcentral.com/submit 